\title{
Bioactive Constituents of Conyza Albida
}

\author{
A. del V. Pacciaroni ${ }^{1}$, L. Ariza Espinar ${ }^{1}$, E. Mongelli ${ }^{2}$, A. Romano $^{3}$, G. Ciccia $^{2}$ and G.L. Silva $^{1}$ \\ ${ }^{1}$ Departamento de Química Orgánica, Facultad de Ciencias Químicas U.N.C., IMBIV- CONICET, Pa- \\ bellón de Ciencias II, Ciudad Universitaria, Córdoba, Argentina \\ ${ }^{2}$ Cátedra de Microbiología Industrial y Biotecnología \\ ${ }^{3}$ Cátedra de Farmacognosia, IQUIMEFA-CONICET, Facultad de Farmacia y Bioquímica, Universidad \\ de Buenos Aires, Argentina \\ E-mail: pacadv@dqo.fcq.unc.edu.ar
}

\begin{abstract}
Alkynes and spathulenol were isolated from Conyza albida (Asteraceae); some of the compounds were lethal against Artemia sp. and cytotoxic against KB cells.
\end{abstract}

\section{Introduction}

Conyza albida Willd. ex Sprengel (Compositae) is a species growing in Argentina. Formerly, it was included as a synonym of $C$. bonariensis var. microcephala Cabr., but, there is enough evidence to consider it a valid entity at species level [1].

Conyza albida is reported to have expectorant, antitussive, and antiinflamatory activities [2,3]. Since $C$. albida usually grows together with $C$. bonariensis populations, it is believed that both species are useful in the treatment of urinary affections, liver diseases, stomach ulcers, and to wash sores [4] as well as an antihelmintic, digestive and diuretic [5,6,7].

There are no phytochemical studies, nor information on the active constituents of $C$. albida. We now present the results on the bioactivity-guided fractionation of an active extract of the leaves of $C$. albida and the evaluation of the activity of the pure compounds against Artemia sp., KB cells and as topoisomerase I inhibitors.

\section{Experimental Procedures}

Dry leaves of Conyza albida were extracted with $\mathrm{CH}_{2} \mathrm{Cl}_{2}$. The total extract $\mathrm{MeOH}-\mathrm{H}_{2} \mathrm{O} 20 \%$ was partitioned between hexane, $\mathrm{Et}_{2} \mathrm{O}$, EtOAc and $\mathrm{H}_{2} \mathrm{O}$. All the extracts, including the water extract, were concentrated to dryness and tested in the brine shrimp toxicity test (BSTT). The hexane and $\mathrm{Et}_{2} \mathrm{O}$ extracts gave positive results with $\mathrm{LC}_{50}=99 \mu \mathrm{g} / \mathrm{ml}$ and $\mathrm{LC}_{50}=96 \mu \mathrm{g} / \mathrm{ml}$, respectively. They were fractionated, guided by the BSTT, by vacuum liquid, centrifugal planar and preparative thin layer chromatographies. The isolates were identified by a combination of the following spectroscopic methods: 
GC-MS, IR, UV, ${ }^{1} \mathrm{H}$ NMR and ${ }^{13} \mathrm{C}$ NMR.

\section{Results and Discussion}

The ethyl ether extract afforded two bioactive fractions with similar chemical composition. After further purification the following compounds were identified: alkenynes $\mathbf{1}, \mathbf{2}[8,9], \mathbf{3}[8,9]$, and spathulenol 4 [10]. The hexane fraction contained alkenynes 1-3 and 1-dodecen-7,11-dimethyl-3methylene [11] which was inactive. This is the first report on compound $\mathbf{1}$, although the trans isomer was obtained by synthesis [12].

\begin{tabular}{|c|c|c|c|}
\hline Compound & $\begin{array}{c}\text { BSTT } \\
(\mu \mathrm{g} / \mathrm{ml})\end{array}$ & KB $(\mu \mathrm{g} / \mathrm{ml})$ & $\begin{array}{c}\text { DNA Topoisomer- } \\
\text { ase I (\%) }\end{array}$ \\
\hline & 1.3 & 7.3 & - \\
\hline
\end{tabular}

Positive controls: BSTT, berberine $\mathrm{LC}_{50}=8.4 \mu \mathrm{g} / \mathrm{ml}$; against $\mathrm{KB}$ cells, colchicine $\mathrm{IC}_{50}=0.02 \mu \mathrm{g} / \mathrm{ml}$.

Acknowledgements: This research was supported by Fundación Antorchas, CONICOR, UBACyT and SECyT.

\section{References and Notes}

1. Ariza Espinar, L. Boletín de la Sociedad Argentina de Botánica 1982, 21, 269. 
2. Toursarkissian, M. Plantas Medicinales de la Argentina 1980, 28.

3. Marzocca, A. Vademécum de Malezas Medicinales de la Argentina, Indígenas y Exóticas 1997, 259.

4. Davyt, D.; Dellacassa, E.; Ferreira, P.; Menendez, P.; Moyna, P.; Vazquez, A. Fitoterapia 1991, $62,519$.

5. González, A.; Ferreira, F.; Vazquez, A.; Moyna, P.; Paz, E.A. J. Ethnopharmacol. 1993, 39, 217.

6. García, G.H.; Campos, R.; De Torre, R.A.; Broussalis, A.; Ferraro, G.; Martino, V.; Coussio, J. Fitoterapia 1990, 61, 542.

7. Ferraro, G.E.; Broussalis, A.M.; Van Baren, C.M.; Muschietti, L.V.; Coussio, J.D. Rev. Latinoamer. Quim. 1988, 19, 141-143.

8. Sanz, J.F.; Marco, J. A. Lieb. Ann. Chem. 1991, 399.

9. Bohlmann, F.; Jakupovic, J. Phytochemitry 1979, 18, 1367.

10. Krebs, H.C.; Rakotoarimanga , J.V.; Habermehl, C.G. Magn. Reson. Chem. 1990, $28,124$.

11. Matsui, M.; Yamamoto, T. Jpn. Kokai Tokkyo Koho, p. 8, CA 125: 168389.

12. Carpita, A.; Neri, D.; Rossi, R., Gazz Chim. Ital. 1987, 117, 481.

This manuscript has been submitted to Planta Medica (1999). 